\title{
Historical Entity of Vijayapur State
}

\author{
Dr. Raja Ram Subedi
}

\section{Introduction:}

At present Vijayapur lies in eastern part of Nepal. There is a dilapidated fort representing the entity of an independent status during the late medieval period of Nepalese history. A Kotche king Sangla Ing, who was the first ruler of Vijayapur state, founded the fort. Pungla Ing succeeded Sangla Ing who was also known by the name of Amara Roy. Kirti Narayan Roy Appa Narayan Roy, Jora Narayan Roy, Ingdi Narayan Roy and Vijaya Narayan Roy succeeded Amara Roy respectively. The seven Kotche kings ruled Vijayapur down to the period of Vijaya Narayan Roy who was the last ruler of that dynasty. ${ }^{1}$ They are said to have been migrated from Kooch Bihar, thus called the Koche kings. The administrative centre of the Kotche dynasty was at Baratappa and later transferred to Vijayapur. Raja Vijaya Narayan Roy was an amicable as well as diplomatic ruler. He established cordial relations with the Kirata subjects of Pheddap region. He made an alliance with Morey Hang, a chieftain of the Kirata, and appointed him as the minister (Dewan). With the help of the Kiratas, Vijaya Narayan Roy was able to repair the old fort of Bhatabhunge Gadhi and shifted his capital from Baratappa to that fort. Then the fort was called Vijayapur Gadhi. Moreover, Hang Khewang was given the rank of minister permanently by the king. ${ }^{2}$ The territory of Vijayapur was expanded up to the Himalayas in the north, river Ganga in the south, Sapta Koshi, Barahakshetra in the west and Jalapaigudi and river Tista in the east. ${ }^{3}$ The eastern border of Vijayapur was not regulated due to the clashes occurred with Sikkim and Bhutan (Bhootang) because those principalities were front door neighbours of Vijayapur.

\section{Vijayapur in the Historical Period}

The oriental classical scriptures do not mention about Baratappa, Morang or Viajyapur. However, there is description of Videha, Mithila and Janakpur as the independent political entities in various classical texts. ${ }^{4}$ Since $8^{\text {th }}$ to $6^{\text {th }}$ century B.C., Videha Janak dynasty is said to have

* Dr. Raja Ram Subedi is Professor in the Central Department of History, Tribhuvan University, Kirtipur, Kathmandu.

1 Iman Singh Chemjong, Kirata kalin Vijayapurko Sanchhipta Itihas, Kathmandu: Kirata Yakthum Chumlung, 2059, p. 20.

2 F.B. Hamilton, An Account of the Kingdom of Nepal, New Delhi: Manjushree Publishing House, 1971, pp. 133-147.

3 Matrika Prasad Koirala, Ancient Nepal 4, Kathmandu: 2025, pp 15-25.

$4 \quad$ T. N. Mishra, 'Videha - Mithila (Seminar paper), pp. 1-2. 
became powerful in Janakpur. The Brizzi Sangha was formed during the first half of the $8^{\text {th }}$ century B.C. Ajatasatru destroyed Brizzi Sangha during the first quarter of the $6^{\text {th }}$ century B.C. ${ }^{5}$

There were sixteen monarchical and eleven non-monarchical states in the northern part of Harivarsha (India) before the incarnation of Lord Buddha. The Videha of Mithila state was under a union of nonmonarchical groups. ${ }^{6}$ In the first half of the $3^{\text {rd }}$ century A.D., there were marital relations between the Gupta rulers and the Lichhavi rulers of Vaisali and Nepal. The Lichchhavis ruled in ancient Nepal. Mithila was under the Lichchhavis of Nepal. The cities have archaeological significance regarding Mithila. Some of them are within the Nepali territory. ${ }^{7}$ Those archaeological remains support the fact that east Nepal and northern Bengal were under the jurisdiction of Mithila domain. After the declining power of Janakpur, the Lichchhavi rulers of Nepal captured the whole area of Mithila under their suzerainty. The stone inscriptions of King Manadeva of Lichchhavi dynasty opine that eastern feudals were the Sontha or Sathaha who were subjugated by the king. The Sontha or Sothaha indicates the inhabitants of east Nepal including those of Mithila Janakpur and further south - east. ${ }^{8}$

East Nepal is still called the Kirata Region. The entire region was divided into 3 main. Those areas were situated in lower hill areas adjoining the Himalaya in the north and Tarai in the south. One source mentions Kirata population in Nepal as $900,000 .^{9}$ Pallo-Kirata directly jostled with Sikkim and Bhutan for its entity. River Tista adjoined Hazary, Rangamutty and Cooch Bihar in the South. ${ }^{10}$ About the history of Vijayapur, Sarat Chandra Das assumes that the former ruler of the Kampachan Valley (Kanchanjangha) were the Magars which may be verified by ruins of forts and settlements in the Kampachan area. The Magar rulers were not liberal to the Sherpa subjects who were Tibetan migrants. The Magar rulers collected exorbitant taxes from Sherpas

5 Upendra Thakur, History of Mithila, Durbhanga: Mithila Institute, 1960, pp. 60-64.

6 B.R. Ambedkar, The Buddha and His Dharma, Nagpur : Buddha Bhoomi Prakashan, 1997, pp. 1-5.

7 Tarananda Mishra, 'Archeological Remains of Videha - Mithila, A Seminar Paper Presented in Royal Nepal Academy Kathmandu Nepal. Held in 2057 V.S., pp. 4-12.

8 Dhana Vajra Bajracaharya, Lichhavi Kalin Abhilekh, Kathmandu: INAS, 2030 V.S. pp 13-60.

$9 \quad$ Mohan Koirala (ed.), Divya Upadesh, Kathmandu: Royal Nepal academy, 2059 V.S., pp. 10-11.

10 William Kirkpatrick, An Account of the Kingdom of Nepaul, New Delhi: Asian Publication Service, 1975, pp. 280-282. 
Raja R. Subedi, Historical Entity of Vijayapur ...

subjects. ${ }^{11}$ It is said that the latter conspired and murdered the Magar King. Later, they Sherpas attended the funeral ceremony. The widow queen requested them to perform religious rites by accepting liquor contaminated with poisonous substances. The Sherpas drank it and finally they met a tragic end. The widow was successful to take revenge of the king's assassination. ${ }^{12}$ The place where the king was cremated is known as Tong-Song-Fong. Then the Sherpas requested the Tibetan government to fight against the Magars. The Tibetan army marched into Kampachan Valley who drove out the Magars. The Magar force resisted for three months but could not defeat Tibetans. The Magars were forced to leave Kampanchan valley and scattered towards the west. However, no evidence supports this version of historical description. ${ }^{13}$

\section{Vijayapur Under the Kotche Kings}

After the fall of Magars from Kampachan valley, the Tibetan Lamas elected Tenzing Lama Guru as the chief of that area. Later on, he was declared the first king of the region. Most of the subjects were Lepchas whose country was called Renzyong. Tibetans called it Dezong. The Kiratas called Su-Him and the Khashas called it Su-Khim. Later it became popular as Sikkim. ${ }^{14}$ The above context supports the fact that the kings of Sikkim were not the original inhabitants of that area. They were the Tibetan migrants.

While tracing remote antiquity of Kathmandu valley, the Gopalas, Ahiras and the Kiratas ruled the valley in different times. The first Kirata King was Yalambara. The $16^{\text {th }}$ generation of King Yalambara was Kuko Hang. Kuko Hang was banished. Consequently, Kiratas were compelled to move to the east. Later, they scattered resulting to various places and formed various tribal groups. It is said that the Lepchas were compelled to move beyond river Tista. Later, there were many wars between Kiratas and the Lepchas. All the Lepchas were compelled to move and settle in Bhootang. ${ }^{15}$

\section{The Kirata Chieftains of the East:}

The Kiratas of East Nepal were mainly divided into ten groups. Thus, they are known as Dasa Kirata. The name of provinces and Kirata chiefs are as follows: ${ }^{16}$

11 W. Brook Northy and C. J. Morris, The Gurkhas, Delhi: Cosmo Publications, 1974, pp. 186-189.

12 Ibid.,

13 Ibid.,

14 Neema Taklinmo, Lapcha Jatiko Utpatti ou Sristiko Ek Jhalko, Darjeeling: Shyam Brothers, 1968 A.D., pp. 1-3.

15 Subba Prem Bahadur Mabohang Limbu, Bhupendra Nath Dhungel, Sankshipta Nepal Itihas, Kathmandu: Kirata Publication 2047 B. S., pp. 83-91.

16 Ibid., pp 90-91. 
1. Takluk Denyok (Chhathar province) -

2. Kurle Yok (Chaubish Miklung Province)-

Khebo Hang Raja.

3. Fedeen Yok (Panch Thar Province)

4. Aang Daang Yok (Ilam Phakphok Province)-

5. Hastapoo Yok (Phikle and East Province)-

6. Pokla Bang Yok (Seven Thari Phhedap)-

7. Poma Jung Yok (Phangden Aathrai) -

8. Takpesu Yok (Tamber Khola Province)-

9. Merinden Yok (Arun Khola Province) -

10. Chhenlung Yok (Thasa Paanch Khapan)-

Mabo Hang Raja.

Pappo Hang Raja.

Lolim Hang Raja.

Linse Hang Raja.

Foyo Hang

Aaklupharoy Raja.

Samb Shreng Hang .

Sisiyen Roy Raja.

Meieng Hang Roy

Half of the provinces were located around Tista. The Kiratas used the pastureland of Tista valley. Thus, that region was called the Kharka or the pasturage of the Dasa Kirata because most of the land was covered with dense forest. Animal products attracted the herdsmen and later they started to settle there. ${ }^{17}$

Archaeological remains of Bandamtan region proved that there was a mixed civilization of various tribal groups during the $12^{\text {th }}$ century. That tribal civilization was a mixture of indigenous Magars, Lepchas and Limbus. ${ }^{18}$ During the first half of the $17^{\text {th }}$ century, Tibetans campaigned for southern migration crossing the Himalayan Passes. They pushed and chased Magars and Kiratas to westward. The Magars and Kiratas resettled in Vijayapur area. Therefore, they were the inhabitants of Vijayapur, Morang, Baratappa, Giddhe Pahad and Tista river valley.

The chieftains and people of Dasa Kirata were expert in archery, physical activities, military organization, building forts and agricultural works. The ten chieftains were united. The Kotche Kings administered the Kirata region. The Kotche Kings were strongly supported by the Kirata chieftains. Those chieftains were called Dewan or Roy. They were given the title of minister for six months in the rotation basis. This tradition continued until the second half of the $17^{\text {th }}$ century. When Morey Hang Dewan was supposed to be appointed as the minister, there occurred a rape case. The Dewan was accused of the case. The princess of the Vijayapur complained about it to the King. The king with the support of the cabinet decided capital punishment for the Dewan. ${ }^{19}$ Baja Hang, the son of the Dewan, was determined to take revenge of his father's death. He begged Mukunda Sen I, the King of Palpa to attack Vijayapur. Consequently, King Mukunda Sen I dispatched a troop under

17 Gyan Mani Nepal, Nepal Sikkim Sambandha, Purbanchal: Nepal Itihas Vikash Samiti, 2041 V. S., pp. 5 -10.

18 Harsha Bahadur Budha Magar, Is Gorkhaland A Reality or Simply Mirage? , Kathmandu: Pashupati Buda Magar, 1994, pp. 1-2.

Hamilton, f. n. no. 2, pp. 132-135. 
Raja R. Subedi, Historical Entity of Vijayapur ...

command of his youngest son Lohanga Sen to support Baja Hang. The troops of Palpa pierced Vijayapur and approached Mahanadi near Silgudhi. After the victory over Vijayapur, the army entered Giddhe Pahad. But a local commander killed Baja Han. However, the Vijayapur state came under the the juridiction of Lohang Sen of Palpa. ${ }^{20}$ Mukunda Sen I divided his kingdom among his sons. Lohang Sen was given the territory of Makawanpur and the eastern parts. Lohang Sen nominated sons of Baja Hang as ministers. He provided local-self-government by inscribing a copperplate mentioning the rights and duties of the chieftains of Dasa Kiratas. ${ }^{21}$

\section{Vijayapur Under the Sen Kings.}

The territory of Lohanga Sen extended from Makawanpur to Purnia and Jalapaigudhi. ${ }^{22}$ The territory of Das Kiratas was divided into two main regions i.e. Khumbuwan and Limbuwan. King Lohang Sen annexed both Limbuwan and Khumbuwan where the local chieftains ran the local administration. Lohang Sen's headquarter was Makawanpur. He renovated a number of shrines, religious centres, and pilgrim sites to revive Hinduism. In this campaign, Dewan Vidyachandra Roy assisted the King and founded the pious shrine of Budha Subba at Vijaypur.

Raghava Narendra Sen who expanded his state to Gandhawara and took the title of Hindupati, Master of Hindus, succeeded Lohang Sen. Gandhawara extends to Purnia, which touches the river Ganga. ${ }^{23}$ Harihar Indra Sen who had done remarkable religious and administrative works succeeded him. During his reign, Makwanpur state was divided into three parts, Makwanpur, Chaudandi and Vijayapur. His son Chhatrapati Indra Sen and his grandson Vidhata Indra Sen respectively became the Kings of Vijayapur. Mandhata Sen succeeded Vidhata Indra Sen. Raghu Nath Inddra Sen was the first and last ruler Vijayapur. His Dewan murdered him. He was succeeded by Karna Sen. Thus, from 1553-1775 A.D., Sen rulers of Palpa ruled over Vijayapur.

\section{Vijayapur Under the Rule of the House of Gorkha}

Prithvi Narayan Shah, the King of Gorkha was determined to unify Nepal. The Gorkhali warriors were well acquainted with the

20 Shaiva Kumar Shrestha, Limbuwanko Aitihasik Jhalak, Dhankuta: Gangadevi Shrestha, 2042, pp. 34-36.

21 Iman Singh Chemjong, Kirat Kalin Vijayapurko Itihas, Kathmandu: Kirat Yakthum Chumlung, 2059 V. S., pp. 90-92.

${ }^{22} \mathrm{Kf} " j\{j / f x$ If\}qfGtdl d'ISt If\}qfGt d'Q/dI . kIZrd ?? If\}qfGtdl xl/ If\}q jlwTotfdl

Yogi Narahari Nath, Skandha Purana Himbat Khanda, Kashi: Yoga Pracharini Samiti, 2013, pp. 105-108.

23 Hamilton, f. n. no. 2. pp. 35-137, Vishnu Prasad Ghimire, Palpa Rajyako Itihans, Chitawan: CDA, 2056, pp. 35-37. 
Vijayapur state. Prithivi Narayan Shah appointed Bakshi Abhiman Singh Basnyat and Sardar Ramkrishna Kunwar to conquer the eastern territory. They successfully conquered both hill and Tarai up to river Tista. ${ }^{24}$ Prithvi Narayan Shah appointed Biswamitra Upadhyaya and Gangananda Aacharya as the agents to settle border dispute with Sikkim. King Prithvi Narayan Shah retained the previous privileges of Kirata chief of Vijayapur region. ${ }^{25}$ Ganga Nanda Acharya was assassinated in Sikkim and Prithvi Narayan Shah issued an order to invade Sikkim. The latter seeked help from Lhasa, but in vain. Sikkim lost the war. As a matter of fact, she had to pay Rs 4000 to Prithvi Narayan Shah as tribute.

After the conquest of Vijayapur two Subbas were appointed to rule the territory. They also advised to annex Sikkim into Nepal. ${ }^{26}$ Kaji Abhiman Singh Basnyat and Dhaukal Singh Basnyat were given the responsibility of Dewani to command 21 companies of Nepalese army. ${ }^{27}$ There was political unrest in Sikkim. Therefore, the king fled to Tibet who was also a disciple of Dalai Lama. Considering this situation, Subba Yoga Narayan Malla, the military commander was not permitted to attack Sikkim. Therefore, river Tista was agreed upon as the the border between Nepal and Sikkim in 1845 V. S. ${ }^{28}$

\section{Conclusion:}

Vijayapur was an independent state during the later medieval ages. Kotche King Sangla Ing was the founder of that state. Baratappa was its capital. Vijaya Narayan Roy was the last ruler of this dynasty. Kiratas served as ministers who were called Dewan and Roy. Lohang Sen of Palpa replaced raja Vijaya Narayan Roy. After King Prithvi Narayan Shah conquered Vijayapur, the separate entity of that state ended. But the privileges given to the Kirata chieftains tended to continue even after it was annexed to Nepal. Kiratas constituted majority in Vijayapur state. They set up local government. Only the sovereign power was vested in the center. Even after the unification of Nepal, local government tended to exist.

$$
* * *
$$

\footnotetext{
24 Chemjong, f. n. no. 21, pp.99-100.

25 Nepal, f. n. no. 17, p. 22

26 Nepal , f. n. no. 17.

27 Yogi Narahari Nath, itihas Prakashma sandhi Patra Sangraha, Vol. 1, Dang: Adhyatmik Sammelan, 2022 V.S., p. 188

28

Nepal, f. n. no. 17, pp. 24-25.
} 